\title{
Introduction to the Integrated Nutrient Management Strategies, and Contribution on Yield and Soil Properties
}

\author{
Mostafa Mohamed Selim \\ Department of Field Crops Research, Agricultural Division, National Research Centre, Dokki, Cairo, Egypt \\ Email address: \\ Selim_family@hotmail.com,selimnrc@gmail.com \\ To cite this article: \\ Mostafa Mohamed Selim. Introduction to the Integrated Nutrient Management Strategies, and Contribution on Yield and Soil Properties. \\ Journal of Plant Sciences. Vol. 9, No. 4, 2021, pp. 139-150. doi: 10.11648/j.jps.20210904.13
}

Received: October 10, 2019; Accepted: November 15, 2019; Published: August 6, 2021

\begin{abstract}
Alleviation of poverty and achieving food security are a significant challenge facing planner worldwide. A way of improving agronomic practices, mainly which has drastic effect on crop growth and yield potential is necessary and acceptable. In this domain, fertilization management has high priority, due to the expensive fertilizers, recently became the costlier input in agriculture. So, rationalization the use of chemical fertilizers is considerable. Replacement a part of chemical fertilizers by organic manure through a simple technique of using minimum effective dose of sufficient and balanced quantities of organic and inorganic fertilizers in combination with specific microorganisms, called INM are a bright solution. Not only for improving and building up of soil fertility but also for increasing the efficiency of chemical fertilizers and make fertilizers more available and most effective for maintaining higher yield without exposing soil native nutrients, ensuring environment and underground water with minimum risks and guaranteeing high profitability. Accordingly, integrated use of chemical fertilizer with organic manure became the quite promising practice not only for maintaining higher productivity but also for greater stability to crop production. Also, (INM) acts as a source of energy for the growth of soil microbes, improvement physical properties of soil, organic carbon and available nitrogen. Additionally, due to their slow realize have great residual effect on subsequent crops. The potential role of INM has been well documented by several investigators, despite some researchers have that, the effects of organic manures are not always have positive contribution and some fields have poor response to organic manures. Such conflicting effect may be due to the presence of high levels of phytotoxins and high $\mathrm{C} / \mathrm{N}$ ratio, particularly in immature manures. So, the key component of INM goal is reaching to most effective and homogeneous combination could get a good fertilization program and effective target of the fertilizers, sufficient, balanced use of their quantity and quality, and straightforwardly uptake by plants for higher yield without jeopardizing soil native nutrients or polluting the environment. Conclusion, INM is a tool, that can offer good options and economic choices to supply plants with sufficient amount of most macro and micronutrients, and also can reduce the dose of chemical fertilizer, create favorable soil physiochemical conditions, healthy environment, eliminate the constraints, safety soil nutrient balance in long run, to an optimum level for sustaining the desired crop productivity and finding safe methods to get rid of agriculture wastes.
\end{abstract}

Keywords: Organic-inorganic Fertilizers, Bio-fertilizer, Integrated Nutrients, Nutrients Balance, Nutrient Management

\section{Introduction and Literature Summary}

Vision world without hunger and poverty intensified by rising standards of living of rural regions, where the majority of poor people live and their full dependence on agriculture for living to fulfill their food demands [1]. The key to eliminate current suffering must lie in the creation of strategic plan that enhances prosperous farming and enable farmers themselves to achieve agricultural growth and reduce poverty.

Thus, the main challenge of the coming few years, lies in the following question? Can agriculture provide the world population with all food needs which are expected to exceed 7.5 billion by the year 2020), [2]. With the view of a growth in land scarcity and an increase in water shortage, most of agriculture plans depend on the use of chemical fertilizers and the production of new high yielding crop varieties. Yet, both components are much expensive and will lead to higher pressure and more responsibilities for the financial investments and consequently will lead to increase in the total costs. Meanwhile the price of fertilizer increases, year by year, 
due to the higher amount of fertilizers needed in the second and third seasons as compared to the first season to maintain current yield production at the economical level. Despite the increase in the quantity of fertilizers application, a part of applied fertilizers and soil native nutrients were already consumed by the current and previous crop, especially in the case of intensive agriculture, where two to three crops are annually cultivated. Moreover, application of inorganic fertilizers is not a pragmatic option for many poor farmers in different regions worldwide, because many poor farmers don't have enough money to pay the claim of fertilizers price, besides its scarcity and unavailability in times of need.

Since ancient time, farmers have known that soil health can be restored by applying organic manure; accordingly, they used to apply farmyard manure regularly and directly after crop harvest. Consequently, the custom of using organic manures after harvesting, has been coupled with restoring soil health and improving soil physical, chemical, and biological properties, particularly in marginal soils, which are already suffering from low organic matter and low native nutrients content; low productivity; limitations and unavailability of essential nutrients [3-7].

Additionally, organic farming system provides organic food, which is preferred by many customers regardless of higher prices. In this context, organic fertilizers, also due to their slow release have greater residual effect on subsequent crops than inorganic nutrient, which is quickly lost by water leaching and runoff to underground water. Therefore, recently escalated calls emerge inviting farmers and agriculture specialists to change their awareness towards substituting part of inorganic fertilizers by cheaper, more sustainable, higher nutrient use of efficient and ecofriendly nutrients, which are originated from natural resources (Compost), under the bold title of INM practices.

Under the heading of INM practices, many sub heads can be introduced, including the use of farmyard manures, natural and mineral fertilizers, soil amendments, crop residues and farm wastes recycling, agroforestry, green manures and compost [6-10].

In contrast, some researchers have concluded that, the effects of organic manures do not always have positive contribution, and some organic materials may indeed be inhibitory to plant growth, perhaps due to the presence of high levels of phyt-otoxins and high $\mathrm{C} / \mathrm{N}$ ratio, particularly in organic materials which are immature $[11,12]$.

Thus, the recycling of organic wastes, by the farmers themselves, may be valuable and acceptable option for many of agriculture planners and numerous farmers to overcome the traditional methods of organic waste disposal, with or without slight risk to the plants, groundwater or ecological pollution and human health to achieve the best use of existing natural resources $[7,13,14]$.

The key component of INM goal is reach the most effective and homogeneous combination that, could lead to good management and effective target of the fertilizers, sufficient, balanced use of their quantity and quality, and straightforwardly uptake by plants for higher yield without jeopardizing soil native nutrients or polluting the environment. It is ultimately viable to achieve such target through the wise application of Integrated Nutrient Management (INM) approach, which is known as a balanced mixture of organic, Inorganic, as well as bioorganic microorganisms in combinations in a different practice (Janssen, 1993). Also, it can improve all characteristics of molecule absorption of macronutrients NPK and micronutrient inputs. In addition, matching the crop nutrients requirements and alleviating constrains of nutrient deficiency without any harmful effects in the environment and products. Contrary, in the case of mismanagement, it always leads to soil degradation, nutrient deficiency and quick soil runoff [7].

Integrated Nutrient Management is also described as the technique of using minimum effective dose of sufficient and balanced quantities of organic and inorganic fertilizers in combination with specific microorganisms to make nutrients more available and most effective for maintaining high yields without exposing soil native nutrients and polluting the environment. Furthermore, many benefits can also be gained from using integrated nutrient management, INM is also, one of the driving forces, able to support the plans of converting marginal lands into productive ones, and therefore fulfill the strategy agenda of increasing cultivated land.

Although, many researchers and specialists might find themselves surprised by the results of INM practices, farmers are still in need of great efforts and also additional assistance from many different disciplines viz., scientific researchers, extension specialists, government sectors, and NGOs to make them well known and able to recognize whole aspects of such practice, for example training program aims at increasing basic knowledge of plant requirements for optimum level of yield production. In the same respect, farmers are also in need to know which form of plant nutrients can be combined with each other to achieve the maximum nutrient use efficiently and how these supplies can be integrated to obtain highest productivity levels within acceptable economic returns and satisfactory environmental impacts. Also, the integration between different disciplines is also necessary $\mathrm{Wu}$ et al., (2014); in various spheres, such as plant breeding, agronomy, soil science, plant nutrition, plant protection, and agricultural engineering.

In addition, intensification of the efforts of extension specialists who are able to transfer research results into practical recommendations, beside government sectors, and NGOs, who are the main reasons for supporting the future success of these technologies and creating responsible entity will be able to market organic products in extensive level.

In conclusion, integrated nutrient management is a tool which can offer good options and economic choices to supply plants with sufficient amount of most macro and micronutrients, and also can reduce the dose of chemical fertilizer, create favorable soil physiochemical conditions, healthy environment, eliminate the constraints, safety soil nutrient balance in the long run, to an optimum level for sustaining the desired crop productivity and finding safe methods to get rid of agriculture wastes [15-18]. 
Global food production needs to be increased at least by $70 \%$ over the current level by 2050 to meet the increase in food demands, which rapidly increases as a result of overpopulation [19]. To achieve this challenging target, agriculture must grow significantly, in consideration of the factors that contribute to increase yield production, which are already reduced or tended to reduce, since they are under placing unprecedented pressure on the natural resources.

Achieving food security is a significant challenge facing agriculture development worldwide in addition to the option of solving highly critical problems to ensure alleviation of poverty. Realizing food security and agriculture sustainability are urgently required, therefore improving many agronomic approaches, which have drastic effect on crop growth and yield e.g., soil nutrient content, crop nutrient requirements and soil nutrient balance are necessary [20]. Among various practices followed by many farmers, some are in need of some improvement, particularly having bad habits regarding the use of a large amount of fertilizer, under the inherited knowledge that without applying a large amount of fertilizers they don't maintain high yields. Such irresponsible practices, which are accepted by many farmers result in the loss of most fertilizers applied and cause some environmental problems and raise the overall costs. Moreover, continuous use of synthetic fertilizers generates serious problems of soil nutrient deficiency, food contamination and damages soil physio-chemical properties through the increase of soil acidity, which lead to hasty deterioration soil health, productivity and both stability and sustainability [21-26].

In spite of the fact that the application of chemical fertilizers has more advantages than disadvantages, it does not always mean that an increase in crop production must be obtained after their application; because a part of the added fertilizers may not be utilized by crop, as it may temporally remain in the soil or may be lost through volatilization or by leaching to underground water, then result in serious problems and dangers and become a source of environmental pollution [27-29]. Considering the above mentioned reasons, and in addition to high costs and declining profitability, scarcity, leaching down to the root zone; groundwater contamination becomes the cause of disease.

Recently, farmers and agricultural specialists, recognize that further application of inorganic fertilizers does not mean that an increase must be induced, then realize the importance of soil fertility through the application of organic fertilizers, that are available, inexpensive, and can be used solely or in combination with other available organic or inorganic resources to enhance soil fertility and bring about higher crop production, without having any undesirable impacts on the environment [23, 24, 30-32].

Concerning the basic materials which can be used in INM system, several investigators discovered that, various materials can be used as a constituent of INM combinations viz., farmyard manures, natural and mineral fertilizers, soil amendments, crop residues and farm wastes recycling, agro forestry, green manures and compost [17]. Such materials are generally seen as a key practice in ecofriendly system to ensure the sustainable production and safety food production [33-41].

Although, recycling of organic wastes into compost is a complex field practice that needs more labors, and may lead to raise the labor and total costs. Yet, in comparison with the many gains that can be attained in the long run such as improving the soil health, ensuring safety of the food produce, to guarantee that the environment will become satisfactory and acceptable technique for many farmers and customers [6]. Thus, thorough application of organic fertilizer leads to restore the soil health and maintain the productivity for long period, regretfully at field scales, the sole application of organic fertilizers to sustain the crop yield at economic level cannot be reliable. Therefore, it must be applied in combination with other fertilizers, which are derived from inorganic sources to meet the crop nutrient requirements.

Currently, the goal of interests of most researchers needs to be modified; the main issue of the most critical researches must be included in managing nutrient programs to provide a safe food supply free from pollutants or at least contains the minimum level of agrochemical contaminants. Furthermore, guaranteeing environment without pollution or at least, a lower level which is one of the huge challenges of the $21 \mathrm{st}$ century $[6,7,16,17]$. Therefore, the great challenge has been converted to optimizing nutrient supplies to maintain high nutrient use efficiency, refining natural resources, modifying agriculture practices to achieve more grain yield per unit area; without jeopardizing the soil, natural resources and improving water use efficiency to produce more crops per drop. All of these are the most important goals, which can be achieved by the implementation of INM program not only at the present time, but also in the near future.

Integrated Nutrient Management (INM) is a scheme that refers to a safest way to dispose of crop residues and produce high quality compost; a balanced and integrated use of both sources of fertilizer together in combinations (organic and inorganic fertilizers) for maintaining soil fertility and providing plants with an optimum level of nutrient requirement over all of cycle life to sustain yield productivity. The key component of INM system includes:

1) Considerable attention must be focused on all possible nutrient sources that can be used as a tool of nutrient sources in planning nutrient input programs for optimizing nutrient use efficiency and high yield production.

2) The forms and quantities of soil nutrient contents in root zone, which is known as soil balance and its availability to cover crop requirements (spatially and temporally).

3) Minimizing nutrient losses, especially in intensive agriculture system [42, 43].

4) Taking all factors affecting the plant /nutrients relationship into consideration to achieve high yield production, which is the main objectives and the major gain of the application of integrated nutrient management (INM), water use efficiency, grain superiority, high economic return, and sustainability [43].

Additional benefits also can be gained, i.e., produce healthy food free from contaminants and chemical residues, which is 
currently accepted and preferred by many customers due to the fact that they are safer and healthier compared to products which are conventionally produced under sole application of synthetic fertilizers, regardless of their high price. Furthermore, adopting such practice also had a contribution and remarkable residual effect on yield and yield components character of the succeeding crop [44-47].

In addition, the studies of [48-52], also came nearly to the same deduction which was mentioned previously and originated in the conclusion that integrated nutrient management of organic and inorganic sources, alongside with biofertilizers is the best way to get maximum benefits from the fertilizers application, particularly in the areas where nutrients are low or limited or in unavailable form, otherwise some troubles will be regarding nutrient uptakes to sustain higher yield and maintain soil health. Furthermore, a part of applied organic manure is being left with a high amount of crop residue after harvesting to the succeeding crop; and these materials will quickly decompose and turn to high quality compost, which can improve soil nutrients content and share in building soil organic matter, which is protect the soil from erosion [53, 54]. With widely predictable benefits from integrated plant nutrient management, it is necessary to make some adjustments in traditional nutrient strategy plan, with particular attention to soil nutrients balance, special consideration must be focused on the fact that native soil fertility is certainly difficult to be regained once again by application of fertilizers $[55,56]$.

Agriculture is a dynamic sector, affected by many variable factors viz., different agro ecological zones, and types of soil texture, followed by farming practices, technologies and variables in commodity markets. Furthermore, crops have different fertilizer needs and different use efficiency, thus, an urgent priority must be done, to look again at the fertilization programs when planning new soil reclamation agendas. Predictable satisfactory yield production will be produced by following integrated nutrient programs, and also could eliminate the constraints, sustain food security, and guarantee soil nutrient balance with magnificent benefits to succeeding crop [57, 58], as well as sustain economic yield with little effect on native soil fertility and minimize the risk in environment pollution $[16,17,59]$.

Therefore, this review article discusses the remarkable contributions of integrated nutrient management accessible in previous literature review under three main topics:

A. Definitions, Concepts, Objectives, Constrains and Advantages of INM.

B. The relationship between INM and a number of factors affected on sustainable agriculture.

C. The main values outcome from application of INM.

\section{Main Topics Address the Integrated Nutrient Management}

The main topics of integrated nutrient management can be discussed under the following topics.

\subsection{Definitions}

Fertilizers are usually classified, according to the source driven into two main categories. The first one is organic source (natural) and the second is inorganic (mineral or synthetic or manmade) source. Integrated nutrient management (INM) is one of the agronomic practices aiming at usage of the harmonious properties of both sources by making a combination that can be used in decreasing the enormous use of chemical fertilizers as well accreting balance between fertilizer inputs and crop nutrient requirement options, which can maintain soil fertility, restore soil health and continuous supply of plant with nutrient requirements to obtain an optimum level of yield production, maximize profitability and subsequently reduce environmental pollution $[17,60,61]$. In conclusion, the definition of integrated nutrient management is a low-to-no-cost effective technology for restoring soil health, as long as they can be produced and used within a same place.

\subsection{Concepts}

Integrated nutrient management is a practice that combines old and modern techniques of fertilizer use and nutrient management. The idea of INM depends on a number of factors, including harmony in nutrient properties, a balance between crop nutrient demands, what sort of nutrient, in general, is available in soil and in farmer's hand, information and skills about the most suitable nutrient can be harmonized in combination, which materials can be safely used that lead to increase nutrient use efficiency. Additionally, it's a method and a way of disposable organic wastes safely and also an effective method of recycling wastes to good quality compost $[6,62]$. The key components of INM concept is increasing farmer awareness about the valuable use of INM practices, invite them to forget the excessive use of chemical fertilizers and encourage them to focus on long-term plan for sustainable agriculture. Moreover, farmers must have greater consideration for environmental impacts and producing safety food rather than only focusing on profit, which can be obtained. Always must remember that safety food is much preferable for many customers, regardless of price, while it can raise farmer returns by following such practices.

\subsection{Objectives}

The main objective of integrated nutrient management is to maintain economic yield for long period with little effect on native soil fertility and environmental pollution, make some changes in farmer's awareness toward ecofriendly technique (organic farming system) for producing healthy food free from contaminants and insuring satisfactory economic return.

\subsection{Constrains (Difficulties)}

Soil corrosion, mining, degradation and also loss of fertility are the main reasons leading to irreversible decrease of plant production and huge damage for sustainable agriculture. Therefore, to sustain soil health and return soil productivity is 
an urgent need to overcome the problem of low soil productivity. Serious efforts have been made including promotion of more productive use of integrated nutrient management, which inessential portion in organic farming system. In addition, considerable attention must be given to determine soil nutrients balance including nutrients absorbed by the current crop accompanied by great attention towards the requirements of succeeding crop. Thus, continual assessment of the changes in the current soil fertility is necessary to determine nutrient loss through crop absorption, erosion, leaching and to mirror soil balance, because quick depletion of soil fertility will be expected as well as reduction in soil organic matter $[63,64]$.

Additionally, there are some constrains facing the progress of integrated nutrient management. Firstly, the difficulties in obtaining FYM and biofertilizers, some poor farmers have some troubles in obtaining organic manure as well as their lack of knowledge, poor advisory services and skills of recycling organic wastes to produce high quality compost. Also, biotic or abiotic stress are ranked to second series and the third will be the poor tillage, whereas the lack of equipments were ranked in the fourth succession. Also, absence of the role of extension services and NGOs to support farmer's and direct their attention to the importance of using integrated nutrient management and its benefits in conserving soil properties, soil nutrient balance, and environmental impacts as well as their role in increasing their profitability. Finally, all of these could hardly be detected and could be added to the above snags.

\subsection{Advantages}

Preparing soil for producing its maximum capacity is an important target and a complex process resulted from the solidarity of many factors, which largely depend on more than one factor to get the best benefits, among others, soil nutrients content which must not only be in appropriate and accurate quantity, but also must be in easy and available form for plant absorption at the right time of plant requirement. Thus, a good nutrient management package, is a way to attain ideal growth and yield levels for most crops at different agro ecological zones, without or with minimum risk in environment (ecofriendly strategy), [17, 65, 66].

This can also be described as a system involving a series of benefits, such as:

1. Systems can improve soil nutrient natives and increase the solubility and availability of fertilizers to be used.

2. Using the harmonious behavior of nutrient supplies and making them match with crop requirements.

3. Offer nutritional balance to crops and lessen the aggressive effects resulting from opposite impact between nutrients factions and nutrient imbalance.

4. Advance and sustain the physiochemical and biological function of soil properties.

5. Reduce the rate of soil degeneration, water and ecosystem by enhancing carbon confiscation, decreasing nutrient losses to ground and surface water forms and/or to environment pollution.
6. Minimizing higher total costs of production and raising farmer returns (increasing profitability).

7. Improve resistance to both stresses biotic and abiotic.

8. An effective method of agricultural practices to ensure healthy food, covering population food demands alongside with many soil and environmental impacts, especially in countries with rapid growth in population.

9. Additional benefits can also be gained; it does not only save the total costs at satisfactory level with an increase in crop production, but also can be easily practiced by farmers, therefore it is considered one of the most promising techniques in line with future needs.

10. INM can have positive effects on the susceptibility or plant resistance against many types of biotic and abiotic stress.

11. Following INM able to explore a larger volume of soil in order to access water and nutrients. Additionally, improved root development enables the plant to absorb water from deeper soil layers and then reflect an increase the ability of crops toward drought resistance.

12. Changes of farmer awareness toward the climate changes from season-to season, which have greater ecological impacts in order to produce safety food rather than achieving higher yield aiming at attaining higher profit.

\section{Relationship Between INM and a Number of Factors Effect on Sustainable Agriculture Production}

\subsection{Integrated Plant Nutrient Management in Relation to Macro and Micronutrients}

Generally, most of the major studies regarding the effect of the application of macro nutrients NPK are mainly focused on testing the rate of application, timing of application, varietal responses and the effect of its integration with numerous of agronomic practices. While, most of the studies related to the effect of micronutrients application have focused on yield quality traits or may also include methods of application, suitable for treating the problems of micronutrients deficiency $[23,52]$. Most of these studies suggested that application of the recommended dose of inorganic fertilizers is more important than being neglected in order to maintain economic yield, especially in low fertile soils [42, 43, 67]. Whereas, other investigators reported that, occasionally the application of inorganic fertilizers may be the reason for prolonging growth period, and also may be the cause of delaying flowering and physiological maturity by $1-2$ weeks, and will lastly lead to a decrease in yield quantity and quality. Above all, imbalanced and continuous use of inorganic fertilizers may result in some problems in micronutrient deficiencies, which become major constraints on productivity, stability and sustainability of soil health [41, 68, 69]. Therefore, INM become one of the most principle practices, which can replace the traditional methods, decreasing the nutrient losses and 
their harmful effects on the environment, while maintaining higher crop yield and advanced profits [70]. Considerable attention to the success of INM is related to the selection of a combination, which can provide plants with different nutrient sources in adequate amount at timing agreeable with the plant requirements, also which has avital role in improving nutrient-use efficiency and can achieve higher yields [71]. Also, integrated nutrient management practices, may be the best way or dominant option for harmonizing utilized totality of the farm wastes that can be used as plant nutrients. In addition, it is not only the most effective practice that can prevent nutrients deficiency, but also strongly related to social issues, especially for poor farmers, who are unable to spend large investments in maintaining soil fertility.

Although, the combination of organic fertilizer with inorganics considered a stock of nutrients which can continuously supply the current crop with their requirements, but it can also be considered as a scheme which have greater residual effect on subsequent crops than sole application of inorganic fertilizers, due to slow release of nutrients over time and its added value in soil organic matter content [31].

In addition, most of current literature revealed that significant attention has been paid to determine the role of integrated nutrient management of organic and inorganic fertilizers on growth and yield, including the use of FYM, green manures, and bio-fertilizers $[72,73]$. In the same respect, the study of [74] on a long-term field experiment, found that continuous application of inorganic fertilizers alone reduces the soil organic carbon level due to low dry matter production and leads to reduction in the return of crop residues to the soil. Keeping these aspects in mind excess or lack of essential nutrients $\mathrm{N}, \mathrm{P}, \mathrm{K}, \mathrm{S}, \mathrm{Ca}, \mathrm{Mg}$ and micronutrients are often called 'limiting factors' because each could limit the plants growth and cause serious problems in most of accumulation process of make the use of integrated nutrient management an essential factor and main reason leading to sustainable agriculture.

Lastly, farmers and researchers cannot neglect the role of the soil microorganism's in controlling nutrient conversions, solubility, availability, release from the soil root zone to plant roots and also the role in absorption and raising nutrient-use efficiency, which can be achieved by following INM system [75-80]. Additional trend was also observed, a decrease in the losses of water and nutrients through leaching, runoff, volatilization, emissions and immobilization [17], which resulted from an increase in soil organic matter contents and improvement of soil physical and hydrological properties.

\subsection{Integrated Plant Nutrient Management in Relation to Environmental Concern and Food Requirements}

Since, early time of $1990 \mathrm{~s}$, the increase of agriculture production for main food crops has been increasing or even tended to decrease, whereas the trend for global food production needs to increase to above 4 billion metric tons by 2050 to cover population needs which are rapidly increasing [19]. However, further increases in farming production have been associated with negative impacts on global change; water scarcity; land degradation; erosion as well as soil nutrient balance besides depletion soil organic carbon, and later soil run off.

Agriculture approaches are the largest contributors to these emissions. Tremendous increase, which has rapidly emerged in recent years, is mainly due to the huge use of synthetic fertilizers and pesticides, especially in the case of intensive agricultural system [17, 81]. Thus, the use of chemical fertilizers particularly nitrogen, phosphorus and potassium (NPK), are the essential factors and main reasons leading to environmental pollution and land erosion, because of their perpetual uses for long time in some developing countries [82, 83]. In addition, the consumption of synthetic fertilizers has risen globally by $49 \%, 19 \%$, and $33 \%$ for nitrogen, phosphorus and potassium, respectively [17].

Some of the current investigations reported that, intensive use of synthetic fertilizers and pesticides did not have a significant contribution in yield increase, this may be due to more than one factor viz., great nutrient losses through leaching, runoff, volatilization, releases and immobilization, or may be owing to low nutrient-use efficiency. Thus, the reverse habits are necessary, and also are essential in devising agriculture strategy plan to find out a way that enables to produce higher yield production for long term periods, encourages conservation natural resources, ecological impacts and global climate change alleviation and adaptation, also matching with the other agricultural program aiming at increasing production and ensuring environment. Accordingly, it is a high time to search for innovative practices which can guarantee higher yield productions without or with minimal risks or further deterioration of our environment. INM technique can thus, play this role and remain the most effective ways to achieve food security, improve environmental quality and to meet growing food demand worldwide without any bad effects, especially in countries has rapid growth population.

Integrated nutrient management (INM), also a practice has too significantly shown impacts by decreasing chemical application through a combination of inorganic and organic fertilizers either with or without bio-fertilizers that could be minimize nutrient applications and thereby nutrient lose, regulate the nutrient supply, warrants soil nutrient balance and thus result in high nutrient-use efficiency, cost reductions, increase profitability, improve resistance to biotic and abiotic stresses [6, 7, 17, 45, 65, 66].

Lastly, INM is a simple system that can create favorable soil condition, able to provide plants with sufficient, efficient and sustainable nutrient source and also is the promising strategy that have made considerable contributions to lessen negative environmental impact, boost both the quantity and quality traits of the global food supplies and increase land expansion with the plan of sustainable and economical agricultural development [82].

\subsection{Integrated Plant Nutrient Management in Relation to Soil Structure and Water Use}

Recently, many findings highlighted that the relationship 
between soil structure and water conserving or water uses liner and largely depends on many factors, among these, soil organic matter, both quality and quantity, due to the fact that soil organic matter is considered the primary peacekeepers of most of soil properties, which are the bases of soil quality physically (structure), chemically (nutrition) and biologically (microorganisms). [93] Reported that, $100 \mathrm{~kg}$ of dry soil that contains $1 \%$ organic matter can hold $30 \mathrm{~kg}$ of water, whereas soil with $5 \%$ organic matter can hold $195 \mathrm{~kg}$ of water. In the same context, several investigators came nearly to the same conclusion [33, 84, 85], and also the relationship between soil structure and soil productivity [17].

Therefore, any further improvement in soil structure creates a favorable condition for plant water relationship without having any undesirable impact on the environment, for example integrated nutrient management can improve soil organic carbon, which is an important indicator of soil structure and can directly indicate the state and type of soil quality, soil fertility and also a proof of the possibility of agriculture sustainability due to the sunny roles in improving soil physical properties viz., nutrient availability, moisture retention, cation exchange capacity, soil $\mathrm{pH}$, microbial community and activity, bulk density and aeration [86-88]. Whereas, other studies reported that application of organic manures with chemical fertilizers through integrated nutrient management system has an effective role in improving physiochemical soil properties, that leads to an improvement in water infiltration, water holding capacity, water flow down, increase soil field capacity, which consequently improve economic water use and water use efficiency, and leads to much water conserving without reversible effects on crop productivity [22, 25, 89].

In addition, further improvement in soil $\mathrm{pH}$ creates a favorable condition of macro and micronutrients absorption. Timely, Truog, 1946 indicated that, $\mathrm{pH}$ is a critical factor to plant nutrients absorption, the largest advantages in plant nutrients up take macro and micro was noticed in soil $\mathrm{pH} 7.0$, even at a minimum dose of the recommended dose of synthetic fertilizers. Currently, several investigators also came to similar conclusions, for example $[52,90,91]$ suggested that acidification and alkalization in the rhizosphere are the dominant factors affecting soil nutrients solubility and availability. In alkaline soils where higher $\mathrm{pH}$ is prevailing, marked decrease in $\mathrm{Fe}, \mathrm{Zn}, \mathrm{Mn}$ and $\mathrm{Cu}$ absorption were observed, because of these elements are highly correlated to lower $\mathrm{pH}$.

Recently, noticeable quantitative and qualitative changes in field management practices, particularly related to the use of organic manure and chemical fertilizers along with biofertilizers. These changes are generally beneficial for improving soil physical, chemical, biological and hydrological properties, which are reflected in significant rate in mitigation; the irreversible adverse effect of the drought stress and make up a significant portion of water conserving, soil degradation and the main effect may be up degraded soil class [16, 36, 92-94]. In the same respect, previous studies of [16], indicated that highly attention must be considering that, some fields have poorly response to nutrient unsystematic application of fertilizers.

\subsection{Integrated Plant Nutrient Management in Relation to Plant Growth and Crop Yield}

Plant growth is influenced by many factors e.g., application the recommended and ideal dose of inorganic and organic fertilizers, which is the essential option and important factor enhancing crop growth, nutrient uptake as well as vital component in supporting crop life cycle and yield potential $[95,96]$. Therefore, superfluous additions of fertilizers are not always means that an increase in crop production must be occurred; a part of added fertilizers may be not absorbed by crop and mostly are remain in soil or may be lost through volatilization or by leaching to underground water, then became dangers and source of environmental pollution.

Several investigations indicate that INM have remarkable benefits and potential role not only on crop growth, but also on sustainable development of agriculture involving environmental impacts. It's well known that rapid decline in soil fertility which leads to low productivity is related to many factors and occasionally closely linked to irresponsible practices followed by farmers, among these, continuous and intensive use of cropping system, excessive use of chemical fertilizers, and negligence of soil nutrient balance in planning agriculture programs [8, 9], intensive cultural practices and ignoring the application of organic manures solely or in combination with inorganic fertilizers $[6,18]$. Therefore, when managing agriculture strategy, significant attention must not be given to fertilization programs only, but also to the sources of nutrients which are matching, homogenous, mixed in such a combination to be available for plant absorption and cover all of crop needs.

Success of INM relies on a number of factors, including appropriate right combination, right dose, right form and application at right time of plant need. The integrated use of organic, chemical and biofertilizers, also has an effective role in improving soil properties [47], enhancing nutrient use efficiency, decreasing nutrients loss, minimizing crop nutrients requirement, increasing cation exchange, water storage capacity and service in sustaining higher yield [10], improve the phyto availability of micronutrients in soil and their uptake by plants [51]. All of these may too work together and play notable role in crop quality. In addition, having effective role, in general, on plant vigor contribution, particularly which are related to root development, water and nutriments uptake and dry matter accumulation. Results of [17, 47, 88, 97-99], indicate that INM has essential role in improving plant growth in terms of plant height, dry weight accumulation, leaf area, LAI, LAD and CGR, which directly have positive effects in raising crop productivity per unit area and consequently lead to increase water use efficiency, water conserving and economic water use. Owing to, the effect of INM on most of crop growth parameters, high crop yields can be achieved even without further application of NPK rates above the recommended dose of the home-grown area [79-81]. 
In this domain, also strong and conclusive indication reported previously by many researchers, indicate that, INM practice can be an effective practice and ecofriendly approach to produce greater yield production and maintain satisfactory profitability to farmers [100-103].

\subsection{Integrated Plant Nutrient Management in Relation to Succeeding Crop}

The bulk of literature highlighted that, long term use of organic and inorganic fertilizers in combination with biofertilizers indicates a better and effective option to get maximum benefits from the soil to the current crops and occasionally may be extended to succeeding crop. Many results also concluded that, the residual effect of bioorganic farming system may double the yield of subsequent cereal crop [44]. Furthermore, [10, 45, 46, 49, 63, 64], suggested that INM is an important tool for assessing the nutrient reserve in soils; restoring soil health and most effective management strategy to advance soil biological and physio-chemical properties, which are vital component in assessing yield and yield contributing components of both preceding and succeeding crop. Such effect on soil biological properties may be due to the role of microorganisms not only in increasing nitrogen fixation, but also in improving the availability and mobility of phosphorus, potassium and iron, thus provide plants with essential components needed for the process of plant development and yield productivity while remediate soil structure by improving its accumulation and constancy [47, 51, 64].

\section{The Main Values of INM}

The main points below are considered the main principles of INM to be considered in planning integrated nutrient management strategies:

1. Adopting INM practices must be compatible with the local farming system, for example field biological condition (weeds, insects and diseases), soil texture, irrigation services and equipment's available and climatic conditions etc.

2. Using both sources of nutrients optimize fertilizers input, increase their use efficiency by crops; reduce their huge request decrease food contaminations, environmental pollution and total costs.

3. Corresponding soil nutrient supplies with crop demand spatially and temporally in order to conserve native soil contents.

4. INM practice reduces fertilizer loss, improve crop potential and increase profitability.

5. In long term improving soil physiochemical properties (biological and hydrological properties).

6. Applying INM practice, on root zone; where the most important process between plant and soil occur, is a "bottleneck" controlling nutrient conversions, solubility, availability, and release from soil to plant roots and absorption. Such exercise can respond to maximize biological potential through enhancing soil microorganism's activity.

\section{Conclusion}

Owing to the bulk of literature presented in this article, can came to the following conclusion:

Less response and declined crop production continually accompanied by restricted use of unbalanced, inadequate and unfit fertilization programs, which are the main factors of the bottlenecks not only to sustain agricultural production, profitability and sustainability, but also deteriorate the soil health, fewer response to the recommended dose of chemical fertilizers and low response of some fields to fertilizer application. Under such condition, the search of the most effective practice have a radical effect on crop growth and yield, is the main step in developing and sustaining agriculture. Among other practices, integrated nutrient management is a tool which can offer good options and economic choices to supply plant with sufficient amount of most macro and micronutrients, and also can reduce the dose of chemical fertilizer, create favorable soil physiochemical conditions, healthy environment, eliminate the constraints, safety soil nutrient balance in the long run, to an optimum level for sustaining the desired crop productivity and finding safe methods to get rid of agriculture wastes.

Special offer also can be gained, a part of applied organic manure is left with a high amount of crop residue after harvesting to the succeeding crop; and these materials will quickly decompose and turn to high quality compost, which can improve soil properties and share in building soil organic matter, which is protect the soil from erosion.

Finally, turned the interest of agriculture specialist's and farmers toward a simple technique can be easily applied, bio-organic farming system, may be valuable and acceptable option for many of agriculture planners and numerous of play makers to make farmers overcome the traditional methods of organic waste disposal, with or without slight risk to the plants, groundwater or ecological pollution and human health and also a principle component of the future success of achieving the best use of existing natural resources for producing healthy food, which is recently became the main concern and preferable choice for many customers, and ensuring sustainability.

\section{References}

[1] T. Wheller and J. Braun (2013). Climate change impacts on global food security. Science 341, 508-513.

[2] Food and Agriculture Organization (FAO) of the United Nations, (2012). FAOSTAT. FAO Database-Statistics Division. Food and Agriculture Organization of the United Nations, Rome. On line at http://faostat.fao.org/

[3] Adeoye, P. A., S. E. Adebayo, and J. J. Musa (2011). Growth and yield response of cowpea (Vigna unguiculata) to poultry and cattle manure as amendments on sandy loam soil plot. Agric. J. 6 (5): 218-221.

[4] Siavoshi, M., A. Nasiri and S. L. Laware (2011). Effect of Organic Fertilizer on Growth and Yield Components in Rice (Oryza sativa L.), J. Agric. Sci. Doi: 10.5539/jas.v3n3p217. 
[5] Rahmann, G., M. R. Ardakani, P. Bàrberi, H. Böhm, S. Canal, M. Chander, M. David, L. Dengel, J. W. Erisman, A. C. Galvis-Martinez, U. Hamm, J. Kahl, U. Köpke, S. Kühne, S. B. Lee, A. K. Loes, J. H. Moos, D. Neuhoff, J. J. Nuutila, R. Oppermann, et al. (2016). Organic Agriculture 3.0 is innovation with research. Organic Agriculture. DOI 10.1007/ s13165-016-0171-5.

[6] M. M. Selim, and A. Al-Owied, Al-Jawhara (2017). Genotypic responses of pearl millet to integrated nutrient management. BIOSCIENCE RESEARCH, 14 (2): 156-169.

[7] M. M. Selim, (2018). Potential Role of Cropping System and Integrated Nutrient Management on Nutrients Uptake and Utilization by Maize Grown in Calcareous Soil. Egypt. J. Agron. Vol. 40, No. 3, pp. 297-312.

[8] Z. Shah et al. 2003. Crop residue and fertilizer $\mathrm{N}$ effects on nitrogen fixation and yields of legume-cereal rotations and soil organic fertility. Field Crops Res., 83, 1-11.

[9] Z. Shah, and M. I. Ahmad (2006). Effect of Integrated Use of Farm Yard Manure and Urea on Yield and Nitrogen Uptake of Wheat. Journal of Agricultural and Biological Science, 1, 60-65.

[10] Khoshgoftarmanesh, A. H, R. Schulin, R. L. Chaney, B. Daneshbakhsh, and M. Afyuni (2010). Micronutrient efficient genotypes for crop yield and nutritional quality in sustainable agriculture, A review. Agronomy for Sustainable Development 30: 83-107.

[11] Craft, C. M. and E. B. Nelson (1996). Microbial properties of composts that suppress damping-off and root rot of creeping bent grass caused by Pythium graminicola. Appl. Environ Microbiol 62: 1550-1557.

[12] M. de Bertoldi (2010). Production and utilization of suppressive compost: environmental, food and health benefits. In: Insam $\mathrm{H}$, Franke-Whittle IH, Goberna M (eds) Microbes at work. From wastes to resources. Springer, Heidelberg, pp 153-170.

[13] A. C. Gaur and G. Singh (1995). Recycling of rural and urban wastes through conventional and vermicomposting. In: Tandon H. L. S., Ed., Recycling of Crop, Animal, Human and Industrial Wastes in Agriculture, FDCO, New Delhi, India, pp. 31-35.

[14] R. A. Abdel-Aziz, and F. N. Al-Barakah (2005). Composting technology and impact of compost on soil biochemical properties. Arab Gulf J. Scientific Research. 23, (2): 80-91.

[15] Garbeva, P., J. D. van Elsas, and J. A. van Veen (2008). Rhizosphere microbial community and its response to plant species and soil history. Plant Soil 302: 19-32.

[16] Zingore, S., P. Tittonell, M. Corbeels, M. T. Van Wijk and K. E. Giller (2011). Managing soilfertility diversity to enhance resource use efficiencies in smallholder farming systems: a case from Murewa District, Zimbabwe. Nutr. Cycl. Agroecosyst. 90, 87-103.

[17] Zhang, F., Z. Cui, X. Chen, X. Ju, J. Shen, Q. Chen, X. Liu, W. Zhang, G. Mi, M. Fan, R. Jiang (2012). Integrated nutrient management for food security and environmental quality in China. Adv. Agron. 116, 1-40.

[18] Samreen, S., S. Zahir and M. Wisal (2014). Residual effect of organic wastes and chemical fertilizers on wheat yield under wheat-maize cropping sequence. Soil Environ. 33 (2): 88-95.

[19] Food and Agriculture Organization (FAO) of the United
Nations (2009). Declaration of the World Summit on Food Security, Rome, 16-18 November 2009. (www.fao.org/wsfs/ world-summit/en/).

[20] Ali, A. M., M. R. Alam, M. S. H. Molla, and F. Islam (2010). Crop productivity as affected by fertilizer management options in Boro-T. cropping pattern at farmer's fields. Bangladesh J. Agri. Res. 35 (2): 287-296.

[21] B. Kacar, and A. Katkat (2009). Plant nutrition /Nobel publication No. 843/ Science and Biology Publication Series No. 29-Ankara, Turkey- 424-533.

[22] Yolcu, H., H. Şeker, M. K. Gullap, A. Lithourgidis, and A. Güneş (2011). Application of cattle manure, zeolite and leonardite improves hay yield and quality of nnual ryegrass (Lolium ultiflorum Lam.) under semiarid conditions. AJCS 5: 926-931.

[23] Suge, J. K., M. E. Omoniyi, and E. N. Omani (2011). Effect of organic and inorganic sources of fertilizer on growth, yield and fruit quality of eggplant (Solanum melongena), Achieves of Applied Science Research, 3 (6): 470-479.

[24] I. A. S. Gudugi (2013). Effects of cow dung and variety on the growth and yield of Okra (Abelmuschus esculentus L.), European Journal on Experimental Biology, 3 (2): 495-498.

[25] Recep İrfan, N., K. Alpaslan, İlker, İnald and T. Veyis (2015). Effects of different organic materials on forage yield and nutrient uptake of silage maize (Zea mays L.) Journal of Plant Nutrition, V (39), 912-921.

[26] Ghulam, R., J. W. Anwar, N. Muhammad, and A. R. Momna (2015). Determination and Evaluation of the Effect of Different Doses of Humic Acid on the Growth and Yield of Wheat (Triticum Aestivum L.). IOSR Journal of Agriculture and Veterinary Science (IOSR-JAVS), 8 (2), Ver. I: 05-07.

[27] Nawab, K., P. Amanullah Shah, A. Rab, M. Arif, M. Azim Khan, A. Mateen, and F. Munsif (2011). Impact of integrated nutrient management on growth and grain yield of wheat under irrigated cropping system. Pakistan J Bot 43 (4): 1943-1947.

[28] Malika, M., M. R. Islam, M. R. Karim, A. Huda and M. Jahiruddin (2015). Organic and inorganic fertilizers influence the nutrient use efficiency and yield of a rice variety BINA dhan 7. Acad. Res. J AgrilSci Res 3 (7): 192-200.

[29] A. R. M. Solaimam, and M. G. Rabbani (2006). Effects of NPKS and Cow dung on growth and yield of Tomato, Bulletin of the Institute of Tropical Agriculture, 29 (1): 31-37.

[30] O. E. Omotayo and K. S. Chukwuka (2009). Soil fertility restoration techniques in Sub-sahran Africa using organic resources, African Journal of Agricultural Research, 4 (3): 144-150.

[31] Tonfack, L. B., A. Bernadac, E. Youmbi, V. P. Mbouapouognigni, M. Ngueguim, and A. Akoa (2009). Impact of organic and inorganic fertilizers on tomato vigor, yield and fruit composition under tropical andosol soil conditions. Fruits, Vol. 64 (4), 1-11.

[32] Yadav, R. L., B. S. Dwivedi, K. Prasad, O. K. Tomar, N. J. Shurpali, and P. S. Pandey (2000). Yield trends, and changes in soil Organic-C and available NPK in a long-term rice-wheat system under integrated use of manures and fertilizers. Field Crops Research 68, 219-246.

[33] Bhadoria, P. B. S, and Y. S. Prakash (2003). Relative influence of organic manures in combination with chemical fertilizer in improving rice productivity of lateritic soil. J. sustainable Agric., 23 (1): 77-87. 
[34] Regmi, A. P., J. K. Ladha, H. Pathak, E. Pasuquin, C. Bueno, D. Dawe, P. R. Hobbs, D. Joshy, S. L. Maskey and S. P. Pandey (2002). Yield and soil fertility trends in a 20-year rice-rice-wheat experiment in Nepal. Soil Science Society of America Journal 66, 857-867.

[35] Sarkar, S., S. R. Singh, and R. P. Singh (2003). The effect of organic and inorganic fertilizers on soil physical condition and the productivity of a rice-lentil cropping sequence in India. Journal of Agricultural Science, Cambridge 140, 419-425.

[36] Yadvinder, S., S. Bijay, J. K. Ladha, C. S. Khind, R. K. Gupta, O. P. Meelu, and E. Pasuquin (2004). Long-term effects of organic inputs on yield and soil fertilityin the rice-wheat rotation. Soil Science Society of America Journal 68, 845853

[37] Jiang, D., H. Hengsduk, T. B. Dal, W. De Boer, J. QI, and W. X. Cao (2006). Long-term effects of manure and inorganic fertilizers on yield and soil fertility for a winter wheat-maize system in Jiangsu, China. Pedosphere 16, 25-32.

[38] W. A. J. M. De Costa and U. R. Sangakkara (2006). Agronomic regeneration of soil fertility in tropical Asian smallholder uplands for sustainable food production. The Journal of Agricultural Science, Cambridge 144, 111-133.

[39] Taylor, B. R., D. Younie, S. Matheson, M. Coutts, C. Mayer, C. A. Watson and R. L. Walker (2006). Output and sustainability of organic ley/arable crop rotations at two sites in northern Scotland. The Journal of Agricultural Science, Cambridge 144-435447.

[40] S. Hossein and F. Ghooshchi (2013). Response of growth and yield of maize to biofertilizers in organic and conventional cropping systems. Intl J Agri Crop Sci., 5 (7): 797-801.

[41] Chen, X. P., Z. L. Cui, P. M. Vitousek, K. G. Cassman, P. A. Matson, J. S. Bai, Q. F. Meng, P. Hou, S. C. Yue, V. Ro"mheld, and F. S. Zhang (2011). Integrated soil-crop system management for food security. Proc. Natl. Acad. Sci. USA 108, 6399-6404.

[42] W. Wu. and B. Ma (2015). Integrated nutrient management (INM) for sustaining crop productivity and reducing environmental impact: A review. Sci. Total Environ, 512-513, 415-427.

[43] A. B. Ghosh (1980). Soil fertility dynamics under different cropping systems. Fertilizer News 26 (9): 64-70.

[44] Prasad, P., V. Satyanarayana, V., Murthy and K. J. Boote (2002). Maximizing yields in rice-groundnut cropping sequence through integrated nutrient management. Field Crop Res. 75, 9-21.

[45] V. Ramamurthy and K. Shivashankar (1996). Residual effect of organic matter and phosphorus on growth, yield and quality of maize. Indian Journal of Agronomy 41 (2): 247-251.

[46] Goyal, S., K. Chander, M. C. Mundra, and K. K. Kapoor (1999). Influence of inorganic fertilizers and organic amendments on soil organic matter and soil microbial properties under tropical conditions. Biol. Fertil. Soils, 29, 196-200.

[47] V. Kumar and I. P. S. Ahlawat (2004). Carry-over effect of bio-fertilizers and nitrogen applied to wheat (Triticumaestivum) and direct applied $\mathrm{N}$ in maize (Zea mays) in wheat maize cropping systems. Indian J. Agronomy, 49 (4): 233-236.
[48] Alam, S. M., S. A. Shah, S. Ali, and M. M. Iqbal (2005). Yield and phosphorus uptake by crops as influenced by chemical fertilizer and integrated use of industrial by-products. Songkla J. Sci. Tech. 27: 9-16.

[49] Zingore, S., R. J. Delve, J. Nyamangara and K. E. Giller (2008) Multiple benefits of manure: the key to maintenance of soil fertility and restoration of depleted sandy soils onAfrican smallholder farms. Nutr. Cycl. Agroecosyst. 80, 267-282.

[50] Schulin, R., A. Khoshgoftarmanesh, M. Afyuni, B. Nowack and E. Frossard (2009). Effect of soil management on zinc uptake and its bioavailability in plants. In: Development and Uses of Biofortified Agricultural Products. G. S. Ban uelos and Z. Lin (eds.). CRC Press, Boca Raton, FL.

[51] Marschner, P. ed. (2012). Mineral nutrition of higher plants, 3rd edn. Waltham, MA, USA: Academic Press.

[52] G. Ghosh, and S. C. Poi (1998). Response of Rhizobium, phosphate solubilizing bacteria and mycorrhiza organism on some legume crops. Environ. Ecol., 16: 607-10.

[53] Ashmita, B., K. B. Kushal, P. Bhattacharyya, and D. Gorh (2017). Integrated nutrient management in wheat grown in a northeast India soil: Impacts on soil organic carbon fractions in relation to grain yield, Soil \& Tillage Research 168, 81-91.

[54] Iqbal Muhammad, A. K., H. Anwar-Ul, M. Waseem Razaza and A. Muhammad (2012). Soil organic carbon, nitrate contents, physical properties and maize growth as influenced by dairy manure and nitrogen rates. Int. J. Agric. Biol., (14), 1, 20-28.

[55] Rahman, M. H., M. R. Islam, M. Jahiruddin, M. Y. Rafii, M. M Hanafi, and M. A. Malek (2013). Integrated nutrient management in maize-legume-rice cropping pattern and its impact on soil fertility. Journal of Food, Agriculture \& Environment Vol. 11 (1): 648- 652.

[56] Chuan, L. M., P. He, M. F. Pampolino, A. Johnston, J. Y. Jin, X. P., Xu et al., (2013). Establishing a scientific basis for fertilizer recommendations for wheat in China: yield response and agronomic efficiency. Field Crops Res.; 140: 1-8.

[57] Paul, F., F. Brentrup, T. Bruulsema, F. Garcia, R. Norton and S. Zingore (2014). Nutrient/fertilizer use efficiency: measurement, current situation and trends. IFA, IWMI, IPNI and IPI.

[58] Zingore, S., H. K. Murwira, R. J. Delve and K. E. Giller (2007) Soil type, management history and current resource allocation: three dimensions regulating variability in crop productivity on African smallholder farms. Field Crops Res. 101, 296-305.

[59] Zhang, F., Z. Cui, M. Fan, W. Zhang, X. Chen and R. Jiang (2011). Integrated soil-crop system management: reducing environmental risk while increasing crop productivity and improving nutrient use efficiency in China. J. Environ. Qual. 40, 1051-1057.

[60] Zhang, H., R. Lal, X. Zhao, J. Xue, and F. Chen (2014). Opportunities and challenges of soil carbon sequestration by conservation agriculture in China. Adv. Agron. 124, 1-36.

[61] Roy, R. N., A. Finck, G. J. Blair and H. L. S. Tandon (2006). Plant Nutrition for Food Security. FAO, Rome.

[62] Tirol-Padre, A., J. K. Ladha, A. P. Regmi, A. L. Bhandari, and K. Inubushi (2007). Organic amendment affects soil parameters in two long-term rice-wheat experiments. Soil Sci. Soc. Am. J. 71: $442-52$. 
[63] Yu, Y. L., L. H. Xue and L. Z. Yang (2014). Winter legumes in rice crop rotations reduces nitrogen loss, and improves rice yield and soil nitrogen supply. Agron. Sustain Dev. 34, 633-40.

[64] B. H. Janssen (1993). Integrated nutrient management: the use of organic and mineral fertilizers. In: van Reuler, H., Prins, W. H. (Eds.), The Role of Plant Nutrients for Sustainable Crop Production in Sub-Saharan Africa. Ponsen and Looijen, Wageningen, The Netherlands, pp. 89-105.

[65] R. Parkinson (2013). System based integrated nutrient management. Soil Use Manag. 29, 608.

[66] Ramachandrappa, B. K., A. Sathish, G. N. Dhanapal and P. N. Babu (2014). Nutrient management strategies for enhancing productivity of dryland crops in Alfisols. Indian J. Dryl. Agric. Res. Dev., 29, 49-55.

[67] Bhattacharyya, P., K., Chakrabarti, and A. Chakraborty (2005). Microbial biomass and enzyme activities in submerged rice soil amended with municipal solid waste compost and decomposed cow manure. Chemosphere 60, 310-318.

[68] R. L. Yadav and M. C. Meena (2009). Available micronutrient status and their relation with soil properties of Degana soil series of Rajasthan. J. Indian Soc. Soil Sci, 57 (1): 90-92.

[69] Gruhn, P., F. Goletti and M. Yudelman (2000). Integrated Nutrient Management, Soil Fertility and Sustainable Agriculture: Current Issues and Future Challenges. International Food Policy Research Institute, Washington DC.

[70] Wu. Wei and Ma. Baoluo (2015). Integrated nutrient management (INM) for sustaining crop productivity and reducing environmental impact: A review. Science of the Total Environment 512-513, 415-427.

[71] Ryan, J., R. Sommer and H. Ibrikci (2012). Fertilizer best management practices: A perspective from the dryland West Asia-North Africa region. J. Agron. Crop Sci., 198, 57-67.

[72] Mgonja, M., P. Audi, A. P. Mgonja, E. Manyasa and H. Ojulong (2013). Integrated blast and weed management and micro-dosing in finger millet. A HOPE Project Manual for Increasing Finger Millet Productivity; International crops research institute for the Semi-Arid Tropics, Patancheru, Hyderabad, Andhra Pradesh, India.

[73] S. Hemalatha and S. Chellamuthu (2013). Impacts of long term fertilization on soil nutritional quality under finger millet: Maize cropping sequence. J. Environ. Res. Dev., 7, 1571-1576.

[74] Akram, M., M. A., Qazi and N. Ahmad (2007). Integrated nutrient management for wheat by municipal solid waste manure in rice-wheat and cotton-wheat cropping systems. Pol. J. Environ. Stud. 16, 495-503.

[75] Chukwuka, K. S. and E. O. Omotayo (2008). Effects of Tithonia green manure and water hyacinth compost application on nutrient depleted soil in South-Western Nigeria Int. J. Soil Sci. 3 (2): 69-74.

[76] Nath, D. J., B. Ozah, R. Baruah, R. C. Barooah and Borah, D. K. (2011). Effect of integrated nutrient management on soil enzymes, microbial biomass carbon and bacterial populations under rice (Oryza sativa)-wheat (Triticum aestivum) sequence. Indian J. Agric. Sci. 81, 1143-1148.

[77] Garai, T. K., J. K. Datta, and N. K. Mondal (2014). Evaluation of integrated nutrient management on boro rice in alluvial soil and its impacts upon growth, yield attributes, yield and soil nutrient status. Arch. Agron. Soil Sci. 60, 1-14.
[78] Marimuthu, S., U. Surendran and P. Subbian (2014). Productivity, nutrient uptake and post-harvest soil fertility as influenced by cotton-based cropping system with integrated nutrient management practices in semi-arid tropics. Arch. Agron. Soil Sci. 60, 87-101.

[79] Bairwa, V., Dahiya, R., Kumar, P., and V. K. Phogat (2013). Effect of long term integrated nutrient management on soil properties, soil fertility, nutrient uptake and crop yields under pearl millet-wheat cropping system. Res. Crops 14, $762-768$.

[80] Peng, S., J. Huang, X. Zhong, J. Yang, G. Wang, Y. Zou, F. Zhang, Q. Zhu, R. Buresh, and C. Witt (2002). Challenge and opportunity in improving fertilizer-nitrogen use efficiency of irrigated rice in China. Agric. Sci. China 1, 776-785.

[81] Mueller, N., J. Gerber, M. Johnston, D. Ray, N., Ramankutty and J. Foley (2012). Closing yield gaps through nutrient and water management. Nature 490, 254-257.

[82] Davidson, E., J. Galloway, N. Millar and A. Leach (2014). N-related greenhouse gases in North America: innovations for a sustainable future. Curr. Opin. Environ. Sustain. 9-10, $1-8$.

[83] Dawe, D., A. Dobermann, J. K. Ladha, R. L. Yadav, B. Lin, R. K. Gupta, P. Lal, G. Panaullah, O. Sariam, Y. Singh, A. Swarup and Q. X. Zhen (2003). Do organic amendments improve yield trends and profitability in intensive rice systems? Field Crops Research 83, 191-213.

[84] M. M. Wahba (2007). Influence of compost on morphological and chemical properties of sandy soils, Egypt. J Appl. Sci Res 3: $1490-1493$.

[85] L. Van-Camp et al., (2004). Reports of the technical working groups established under the thematic strategy for soil protection. EUR21319 EN/3. Luxembourg: Office for Official Publications of the European Communities.

[86] Zhao, P., J. Li. Wang, Y. Chen, X. Ying and S. Liu (2009). The effects of two organic manures on soil properties and crop yields on a temperate calcareous soil under a wheat-maize cropping system. Mogotsi. In: Brink, M. \& Belay, G. (Editors). PROTA 1: Cereals andpulses/Céréalesetlégumessecs. PROTA, Wageningen, Netherlands. 2006.

[87] Mohammad, W., S. M. Shah, S. Shehzadi and S. A. Shah (2012). Effect of tillage, rotation and crop residues on wheat crop productivity, fertilizer nitrogen and water use efficiency and soil organic carbon status in dry area (rainfed) of north-west Pakistan. J. Soil Sci. Plant Nutr, 12 (4), 715-727.

[88] Sönmez, I., M. Kaplan and S. Sönmez (2008). Effect of chemical fertilizers on environmental pollution and its prevention methods. Batı Akdeniz Tarımsal Araştırma Enstitüsü Derim Dergisi 25: 24-34 (in Turkish with an abstract in English).

[89] Haigang, Li., S. Jianbo and F. Zhang (2010). Phosphorus uptake and rhizosphere properties of intercropped and monocropped maize, faba bean, and white lupin in acidic soil. Biol Fertil Soils, 46: 79-91.

[90] Sarwar, G., N. Hussain, H. Schmeisky, S. Muhammad, M. Ibrahim and E. Safdar (2008). Improvement of Soil Physical and Chemical Properties with Compost Application in rice-wheat Cropping System. Pakistan Journal of Botany, 40 (1): 275-282. 
[91] Esilaba, A. O., J. B. Byalebeka, R. J. Delve, J. R. Okalebo, D. Ssenyange, M. Mbalule, and H. Ssali (2004). On farm testing of integrated nutrient management strategies in eastern Uganda. Agric. Syst. 86, 144-165.

[92] N. C. Brady and R. R. Weil (2005). The nature and properties of soil. 13th ed. New York, NY, USA: MacMillan Publishing Co.

[93] Yang, X. Y., W. D. Ren, B. H. Sun and S. L. Zhang (2012). Effects of contrasting soil management regimes on total and labile soil organic carbon fractions in loess soil in China. Geoderma 177-178, 49-56.

[94] Behera, U. K., A. R. Sharma, and H. N. Pandey (2007). Sustaining productivity of wheat-soybean cropping system through integrated nutrient management practices on the Verticals of central India. Plant Soil 297, 185-199.

[95] Mavi, M. S. and D. K. Benbi (2008). Potassium Dynamics under Integrated Nutrient Management in rice-wheat system. Agrochemical 52, 83-91.

[96] Camara K. M, W. A. Payne and R. A. Rasmussen (2003). Long term effect of tillage, nitrogen and rainfall on winter wheat yield in the Pacific Northwest. Agron. J., 95, 828-835.

[97] K. M. Hati et al., (2006). Effect of inorganic fertilizer and farmyard manure on soil physical properties, root distribution, and water use efficiency of soybean in vertisols of central India. Bioresour. Technol., 97 (16), 2182-2188.

[98] Deksissa, T., I. Short and J. Allen (2008). Effect of soil amendment with compost on growth and water use efficiency of Amaranth. In: Proceedings of the UCOWR/NIWR Annual Conference, International Water Research Challenges for the 21 st Century and Water Resources Education, July 22-24, 2008, Durham, NC, USA.

[99] Cheuk, W., K. V. Lo, R. M. R. Branion and B. Fraser (2003). Benefits of sustainable waste management in the vegetable greenhouse industry. J. Environ. Sci. Health, 38, 855-863.

[100] Sarwar, G., N. Hussain, H. Schmeisky and S. Muhammad (2007). Use of compost an environment friendly technology for enhancing rice-wheat production in Pakistan. Pakistan Journal of Botany, 39 (5): 1553-1558.

[101] Abedi, T., A. Alemzadeh, and S. A. Kazemeini (2010). Effect of organic and inorganic fertilizers on grain yield and protein building pattern of wheat. Aust. J. Crop Sci., 4 (6), 384-389.

[102] S. Ghosh et al. (2010). Management of soil quality and carbon sequestration with long-term application of organic amendments. In: Proceedings of 19th World Congress of Soil Science, Soil Solutions for a Changing World, August, 1-6, 2010, Brisbane, Australia, 146-149. 